\title{
Extreme firn metamorphism: impact of decades of vapor transport on near-surface firn at a low-accumulation glazed site on the East Antarctic plateau
}

\author{
Mary ALBERT, ${ }^{1,2}$ Christopher SHUMAN, ${ }^{3}$ Zoe COURVILLE, ${ }^{1,2}$ Robert BAUER, ${ }^{4}$ \\ Mark FAHNESTOCK, ${ }^{5}$ Ted SCAMBOS ${ }^{4}$ \\ ${ }^{1}$ US Army Cold Regions Research and Engineering Laboratory, 72 Lyme Road, Hanover, NH 03755-1290, USA \\ E-mail: mary.r.albert@erdc.usace.army.mil \\ ${ }^{2}$ Dartmouth College, Hanover, NH 03755-8000, USA \\ ${ }^{3}$ NASA Goddard Space Flight Center, Code 971, Greenbelt, MD 20771, USA \\ ${ }^{4}$ National Snow and Ice Data Center, University of Colorado, Boulder, CO 80301, USA \\ ${ }^{5}$ Center for the Study of Complex Systems, University of New Hampshire, Durham, NH 03824, USA
}

\begin{abstract}
Snow and firn properties control the transport of vapor, gases and water between the atmosphere and the underlying strata. An understanding of this transport and the properties that control it is important for predicting air-snow transfer of chemical species and for interpreting ice cores. Remote-sensing images of East Antarctica show large areas of alternating light and dark bands. These low-amplitude, long-wavelength features have glazed downwind faces and rough upwind faces and are called megadunes. The first linked measurements of the permeability and the associated microstructure for a glazed area within a well-defined megadune area are reported in this paper. Permeability and density were measured, along with grain-scale properties derived from digital image processing of preserved thick sections, at this cold, low-accumulation glazed site. A clear layering pattern exists. In the top meter the firn density ranges from 0.24 to $0.50 \mathrm{~g} \mathrm{~cm}^{-3}$. Permeability measurements range from $50 \times 10^{-10}$ to $200 \times 10^{-10} \mathrm{~m}^{2}$, several times greater than corresponding profiles from warmer, higheraccumulation sites like Siple Dome, Antarctica. It is shown that buoyancy-driven natural convection may be important in post-depositional processes in very cold, low-accumulation sites like this.
\end{abstract}

\section{INTRODUCTION}

High-elevation regions of the East Antarctic plateau have large areas covered by megadunes, which are surface waveforms with low amplitude $(2-5 \mathrm{~m})$ but long wavelengths $(2-5 \mathrm{~km})$. When viewed from an airplane, these features appear as long waves of alternating dark and light bands. The bands also appear in remotely sensed images, because of differences in microwave backscatter (Fahnestock and others, 2000). Megadunes regions typically have low accumulation rates and mean annual temperatures of -45 to $-60^{\circ} \mathrm{C}$, and they experience constant katabatic winds. Early satellite images (Swithinbank, 1988) provided the first descriptions of these regions. Snow pits dug by early traverse teams in Antarctica (Giovinetto, 1963; Picciotto and others, 1970) reported areas with low accumulation. Giovinetto (1963) reported findings of large grain-sizes and significant recrystallization along with thin layers attributed to annual layering, and suggested that sublimation over a period of years may lead to obliteration of originally faint horizons. Many of Giovinetto's measurements seem likely to have been made at a megadune site, but they were not recognized as such at the time because the traverse parties did not have the advantage of seeing the larger dune-field pattern from above. The nearest reported accumulation rates are those from Vostok, $450 \mathrm{~km}$ from the study site, with an accumulation rate of $21 \mathrm{~mm} \mathrm{a}^{-1}$ w.e. (Ekaykin and others, 2002). The D6 site in a megadune area $600 \mathrm{~km}$ away from the study site (Frezzotti and others 2002) includes accumulations that vary spatially between 7 and $35 \mathrm{~mm} \mathrm{a}^{-1}$ w.e., the lower being in a glazed area. Glazed surfaces have been noticed at other locations in Antarctica (Fujiwara and Endo 1971; Goodwin 1990; Goodwin and others 1994). Fuji and Kusunoki (1982) discuss the role of seasonal sublimation and condensation in the formation of glazed firn.

More recent studies have shown that the light bands are rough areas on the upwind (and uphill) slopes of the dunes, and the dark bands are glazed areas with extensive recrystallization on the downwind slopes (Frezzotti and others, 2002). Frezzotti and others (2002) discuss mechanisms for the banding, which is due to closely linked interaction between the ice sheet and the atmosphere. The recent Italian traverse through a portion of one such dune field documented radar and global positioning system (GPS) investigations of the subsurface layering in the firn. They found that the upwind faces are covered with large sastrugi, while the downwind faces have glazed surfaces with extensive snow recrystallization (Frezzotti and others, 2002). Because the megadune features cover large areas in East Antarctica, questions may arise about the possibility that at one time the Vostok location was subject to postdepositional air-snow transfer processes similar to those currently occurring at this site in the megadunes. The relationship of megadune features to the underlying bedrock is not well understood, and the history of the nature of the ice-air interface in the Vostok area remains a question. However, post-depositional processes can alter concentrations in the near-surface snow and firn, and an understanding of the processes may be helpful in gaining additional climate information from ice-core records (Cunningham and Waddington, 1993).

The purpose of this paper is to present preliminary results 


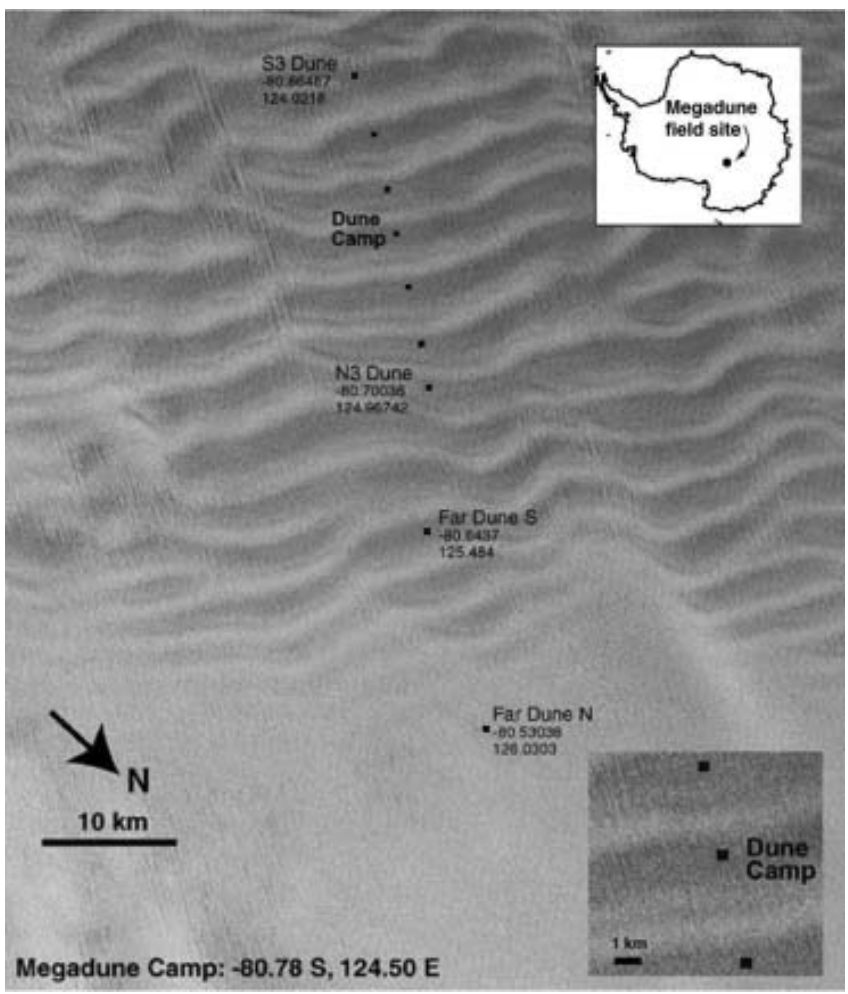

Fig. 1. Location of the glazed measurement site. Landsat 7 Enhanced Thematic Mapper Plus (ETM+) band 8 image ( $15 \mathrm{~m}$ pixel ground equivalent size in original version), path 67 , row 119 , acquired 31 December 1999.

from the first season of a 2 year field measurement campaign designed to conduct detailed glaciological studies of representative areas of the megadunes. The first-year results include field measurements made in December 2002 at a glazed site $\left(80.78^{\circ} \mathrm{S}, 124.5^{\circ} \mathrm{E}\right)$ in the center of a welldefined dunes area. Figure 1 shows the location of the study site. Severe weather greatly impacted the logistics of the first year (2002) of this study, allowing only 1 day of on-site measurements of the physical characteristics of the snow and firn. Nevertheless, from pit sampling and very shallow firn cores shipped to the US Army Cold Regions Research and Engineering Laboratory (CRREL) for analysis, we were able to obtain the first measurements of the snow and firn permeability and quantitative microscopy of the nearsurface microstructure within the megadune area. This paper describes preliminary measurements of the permeability, density and thick-section microstructure at a glazed site in the megadunes.

\section{METHODS}

Field data from the glazed megadune site include snow-pit measurements of the stratigraphy, density, photography, and preserved thick sections of near-surface firn for digital image processing. A hand-operated drill with a fiberglass core barrel (approximately $10 \mathrm{~cm}$ in diameter) was used to drill near-surface cores. The firn was sufficiently well sintered to permit careful collection of intact samples. Several cores, each approximately $1 \mathrm{~m}$ long, were retrieved; one core was drilled to $4 \mathrm{~m}$ depth in the short visit to the site. Great care was taken in handling the fragile firn pieces, which were sealed in plastic sleeves and packed in snow in core boxes

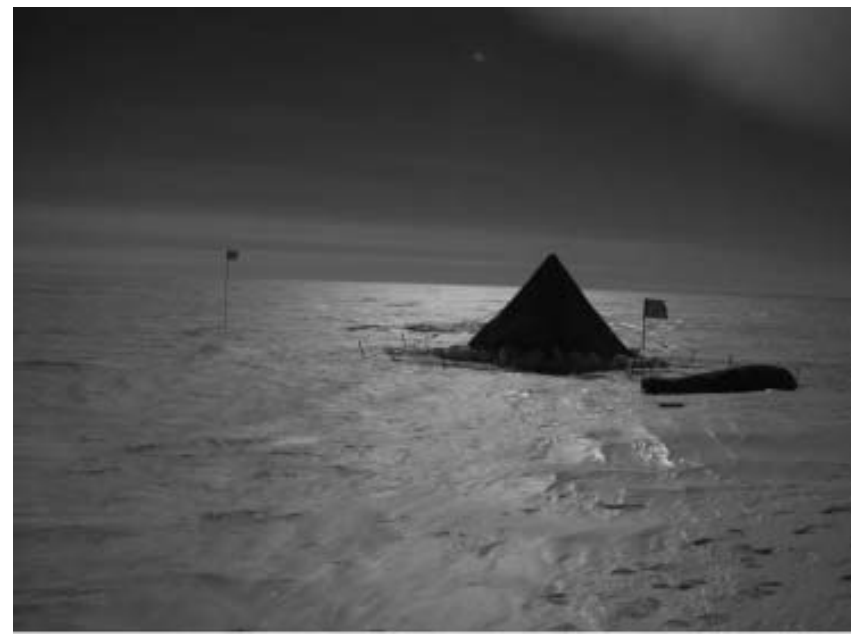

Fig. 2. The glazed site, with a tent shown for scale.

for shipment back to CRREL for analysis. Most of the top meter of the carefully packed firn core survived the shipping processes, with crumbling of samples occurring only in several of the most delicate layers. At the time of submission of this paper, the firn-core pieces not described here are being used for measurements of inert gas diffusivity, after which they will be analyzed for finer-scale permeability and microstructure.

The pit was dug in an undisturbed region. The face of the pit was shaved, and another pit was dug approximately $10 \mathrm{~cm}$ behind the sampling pit in order to use backlighting to view the stratigraphy. Samples for snow density measurements were made with a $100 \mathrm{~cm}^{3}$ box cutter at $3 \mathrm{~cm}$ increments down through the side of the pit. Because of the short time at the site, on-site field measurements of permeability could not be made in the pit.

From the field pit measurements, intact samples of nearsurface firn were preserved in pore filler for quantitative microscopy following the procedure of Perla (1982). The snow samples, each several centimeters thick, were carefully cut into rectangular sample containers. Chilled dimethyl phthalate was poured into free space around the edges of the sample and allowed to wick into the sample. Once the sample was saturated, it was frozen for shipment back to the laboratory. At the laboratory, the samples were cut, fixed onto support plates and microtomed, and the ice crystals were allowed to sublimate. A fine-grained dark powder was then used to fill the voids where the crystals had been, and the sample was wiped level and imaged using a high-resolution digital camera. A digital image-processing program, Image Processing Workbench, was used to process each image so that the original snow crystal space appears white, and the program was used to determine grain-scale measurements of grain-size and pore size for the sample.

Preliminary measurements of permeability were made on pieces of the cores that arrived at CRREL in spring 2003, using a custom permeameter (Albert and others, 2000). A special flexible membrane sample holder, developed and tested at CRREL especially for core measurements, facilitated the measurements by eliminating edge effects. The permeameter draws air through the sample, and measures the pressure drop and flow rate through the sample. Approximately ten measurements are taken on each sample, incrementally increasing the flow rates. Only those meas- 


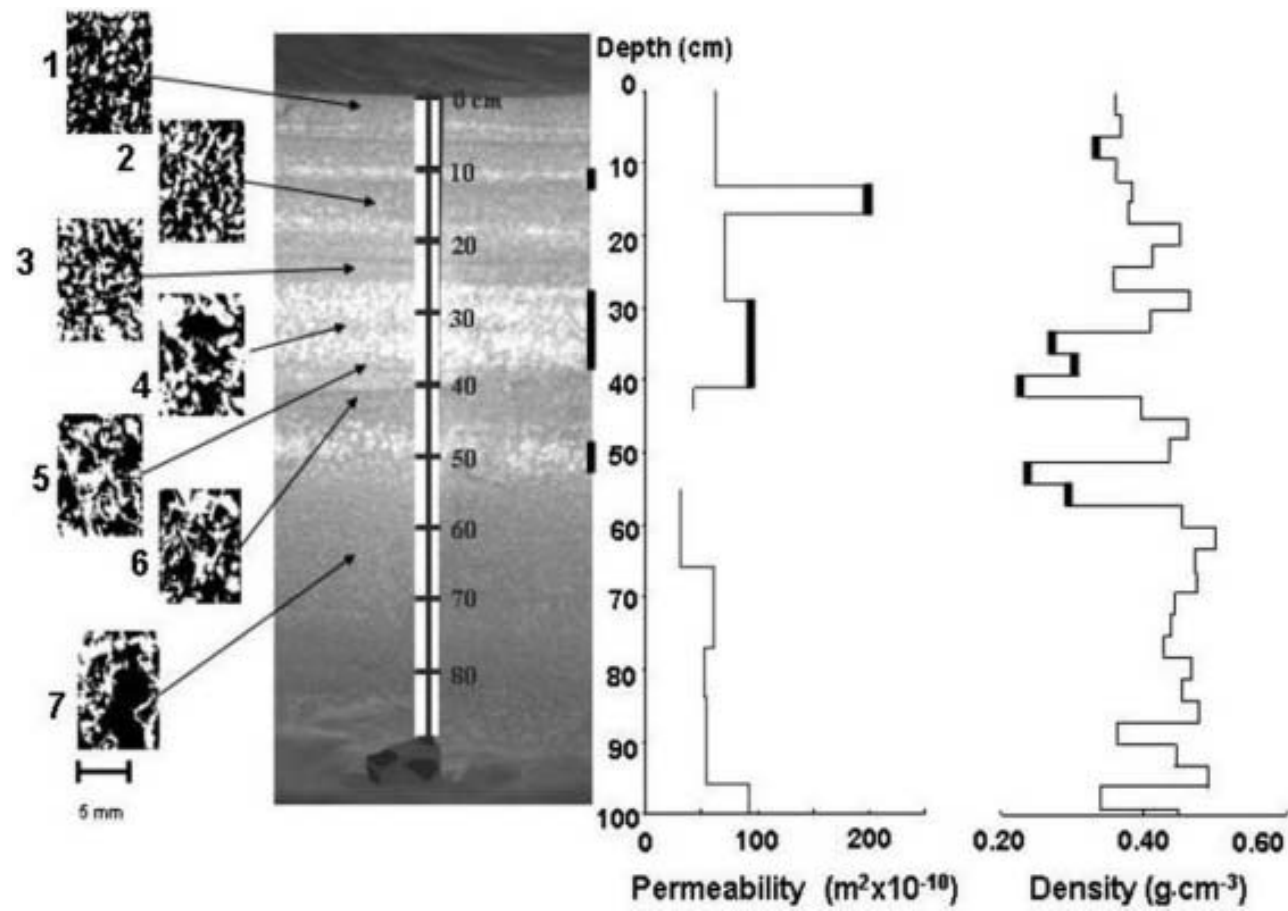

Fig. 3. Firn characteristics of the top meter at the megadune glazed site. Shown are seven thick-section images from several locations, a photograph of the pit layering, the permeability measured from a nearby firn core, and the density measured at one side of the pit. Highlighted areas indicate corresponding layers. The thin ice crusts at 5.5 and $23 \mathrm{~cm}$ are visible as faint dark lines in the photograph.

urements falling within the linear (Darcy) range are used to determine the permeability. This technique typically has a maximum variation of $3 \%$ between the highest and lowest of ten measurements on a single sample.

\section{RESUITS}

Figure 2 shows the surface glazing at the study site. The firn surface at the study site was covered with an ice glaze approximately $2 \mathrm{~mm}$ thick. In several places the glaze was underlain by several monograin ice crusts that sandwiched coarse hoar crystals. Figure 3 shows the stratigraphy of the top meter of firn. A distinct layering pattern can be observed, with coarse-grained layers interspersed with layers of finergrained firn. In the photograph the coarse-grained layers appear as lighter-colored bands. Thin ice crusts observed in the near-surface included a thin $(<1 \mathrm{~mm})$ discontinuous layer at $3 \mathrm{~cm}$; a continuous, $1-2 \mathrm{~mm}$ thick ice crust at $5.5 \mathrm{~cm}$; and a $2 \mathrm{~mm}$ thick crust at $23 \mathrm{~cm}$. A few discontinuous, monograin ice crusts were observed between depths of $23 \mathrm{~cm}$ and $1 \mathrm{~m}$. These were not the result of melt but rather were the result of buffing and polishing of the surface by the wind. The coarse layers in the top meter have very large, faceted crystals along with some cup-shaped hoar. These layers were present at depths of 10-12, 17-18, 26-38 and $46-50 \mathrm{~cm}$. The layers of finer firn were composed of large, solid-faceted crystals.

The firn is clearly layered. However, in contrast to polar sites with high annual accumulation, we hypothesize that the layers most clearly visible in Figure 3 might not be seasonal features, especially not the layers deeper than about $20 \mathrm{~cm}$. The accumulation rate at the site is unknown, but if it is similar to the accumulation rate of the Vostok site or the D6 site on the Italian traverse (Frezzotti and others, 2002), the top meter of firn may represent somewhere between roughly 40 and 140 years of accumulation. This suggests that the layers visible in Figure 3 might represent deposition patterns on a scale of years. As described in the discussion of metamorphism below, thick, coarse-grained layers may represent a period of years where the accumulation rate was very low, allowing vapor transport leading to metamorphosis and grain growth when that firn was near the surface. The finer-grained layers at depth may represent a period of time with higher accumulation. Higher accumulation rates lessen the residency time at the surface, resulting in slower grain growth. Further investigations, including chemistry and isotope analyses, will allow us to better determine the nature of the accumulation rate at the site.

Images from selected thick-section samples of firn microstructure taken in the pit are also shown in Figure 3. In these images, which represent a two-dimensional slice through the firn, the white areas represent the crystals, while the dark areas represent the pore space. Mean grain-size and pore intercepts for the seven samples are given in Table 1. Unlike surface wind packs measured at eight sites across West Antarctica, which typically have grain-sizes less than $0.5 \mathrm{~mm}$ (personal communication from U. Leeman, 2003), the mean grain-size in the surface wind pack at the glazed site is close to $1 \mathrm{~mm}$. The increase in grain-size with depth is evident in the images as well as in Table 1. The coarse layer that exists at approximately $26-38 \mathrm{~cm}$ depth is composed of large individual crystals, with aggregate sizes of several centimeters. These faceted snow crystals, probably many years old, are the result of temperature gradient metamorphism.

In many seasonal snow sites, and at some high-accumulation polar sites, the presence of snow and firn with large grain-sizes implies that the snow has a low density, where low density is taken as $<0.3 \mathrm{~g} \mathrm{~cm}^{-3}$ in the top meter. While distinct differences in density can be seen with depth (Fig. 3), the density in the top meter at this site ranges from 
Table 1. Grain-size and mean pore intercept from digital image processing of preserved thick sections of the firn

\begin{tabular}{lccc}
\hline Sample & $\begin{array}{c}\text { Depth } \\
\text { cm }\end{array}$ & $\begin{array}{c}\text { Grain-size } \\
\mathrm{mm}\end{array}$ & $\begin{array}{c}\text { Mean pore intercept } \\
\mathrm{mm}\end{array}$ \\
\hline 1 & 1 & 0.78 & 1.68 \\
2 & 16 & 0.84 & 1.19 \\
3 & 25 & 0.87 & 1.01 \\
4 & 30 & 1.03 & 1.32 \\
5 & 38 & 1.08 & 1.35 \\
6 & 42 & 1.02 & 1.30 \\
7 & 64 & 0.94 & 1.54 \\
\hline
\end{tabular}

0.24 to $0.50 \mathrm{~g} \mathrm{~cm}^{-3}$. The near-surface snow and firn at this site cannot be characterized as being primarily low-density. There is a significant amount of mass in the firn in the form of firn crystals, but the crystals are large and there are large interstitial pore spaces. Clearly, temperature gradient metamorphism has resulted in the sublimation of small crystals and the growth of large crystals.

While the firn at this site has a medium to high density, it is at the same time very porous, and the pores are well connected, as evidenced by the permeability profile. Preliminary measurements of permeability from a shallow core are shown as a function of depth in Figure 3. Note that in this figure, the photograph of the stratigraphy was taken in a backlit pit, the density profile was measured in the pit approximately $1 \mathrm{~m}$ along the wall from the photographed section, and the permeability was measured from a firn core drilled several meters from the pit. Because in nature the layering is never perfectly uniform, there are small differences in the depth location of individual layers between the three measurements. In Figure 3, we have highlighted measurements of several corresponding layers to help in visualizing the properties as a function of layer type. The permeability measurements in this figure were from core segments each approximately $10 \mathrm{~cm}$ long; some of the measurements include several layers. Continuing work in the coming year will result in measured diffusivities along with a finer-resolution permeability profile. The surface glaze in this sample was cracked, so its permeability could not be measured. However, an intact piece of surface glaze certainly would have had a lower permeability than the surface wind pack, which had a permeability of approximately $50 \times 10^{-10} \mathrm{~m}^{2}$. Glazed surfaces and even much thicker ice layers, such as those resulting from true melt such as in seasonal snow, while usually having a lower permeability than the surrounding snow, are not impermeable (Albert and Perron, 2000).

The overall permeability at the glazed site is significantly greater than at several deep ice-coring sites. For comparison, in Figure 4 the permeability at this site is plotted against near-surface profiles from Summit, Greenland (Albert and Shultz, 2002), and from Siple Dome, Antarctica (Albert and others 2000). It is evident that, with the possible exception of the surface glaze itself, the megadune firn at the glazed site is more permeable than that at either Summit or Siple Dome, especially in the top $50 \mathrm{~cm}$ The only existing measurements of accumulation rate in this area of East Antarctica are $21 \mathrm{~mm} \mathrm{a}^{-1}$ w.e. at Vostok (Ekaykin and others, 2002) and $7-35 \mathrm{~mm} \mathrm{a}^{-1}$ in a megadune area (Frezzotti and

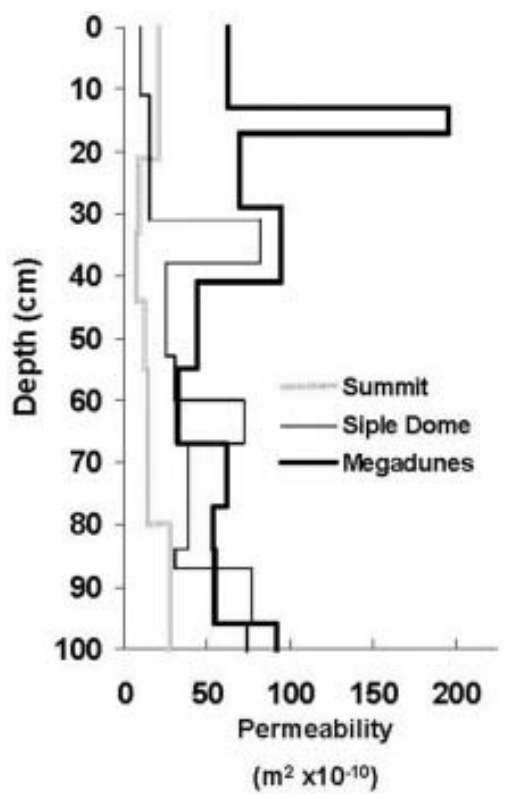

Fig. 4. Comparison of the permeability of a glazed area at the megadune site with measurements from Summit, Greenland, and Siple Dome, Antarctica.

others, 2002). In contrast, the current accumulation rate is approximately $240 \mathrm{~mm} \mathrm{a}^{-1}$ w.e. at Summit and $110 \mathrm{~mm} \mathrm{a}^{-1}$ at Siple Dome. The lower accumulation at the megadune site means that the near-surface firn has been exposed to decades of temperature gradients and metamorphism. Even under these extremely cold conditions, vapor transport and metamorphism have created a high-permeability firn with large crystal sizes but not unusual densities.

Accumulation is not the only major difference between the megadune site and Summit and Siple Dome. Both Summit and Siple Dome have mean annual temperatures much higher than the megadune site. Because air that is warmer can hold more water vapor than air that is colder, the higher mean annual temperatures at Summit and Siple Dome would allow more near-surface vapor exchange during the course of a year than at megadunes. However, there are multiple mechanisms of vapor transport at the megadune site that, in addition to a long surface exposure time, could enhance firn metamorphism.

Snow and firn undergo metamorphism from sublimation and condensation with vapor transport. Vapor diffusion occurs all the time in snow and firn because of temperature gradients driven by changing weather patterns and diurnal and seasonal temperature changes. Even though the temperatures at the megadunes site are very low (so the air can hold relatively little water vapor), exposing firn to a relatively small amount of yearly vapor transport can result in a lot of metamorphism over many years or decades. Measurements of firn temperature in Antarctica (e.g. Brandt and Warren, 1997) show that temperature gradients caused by diurnal effects are greatest in approximately the top $20 \mathrm{~cm}$ of firn, and seasonal temperature swings primarily impact the top 2-4 m. Exposing firn to diurnal and seasonal temperature gradients over many years causes near-surface vapor diffusion that induces vapor-driven redeposition and crystal growth in the top meters of firn. The long-term proximity of the firn to the atmosphere and the relatively strong temperature gradients in the top meters at the 
megadunes site have contributed to a large amount of metamorphic crystal growth.

Vapor transport can be further enhanced by wind-driven interstitial air movement due to ventilation (Albert, 2002), especially in high-permeability firn. The higher permeability of megadunes, compared to Summit and Siple Dome, makes the site more prone to ventilation than either of the other sites. While the surface glaze at the megadune site is visually striking and less permeable than the underlying (extremely high-permeability) firn, it is not an impermeable snow-air interface. In addition, thermal cracks exist in the surface glaze at the megadune site in polygonal patterns not unlike those observed elsewhere in Antarctica. For example, Fujiwara and Endo (1971) show glazed surfaces with both narrow and wide polygonal cracks at a site on a traverse from Syowa station to the South Pole. The naturally occurring polygonal cracks at the megadune site may provide exposure patterns to the underlying firn that may enhance vapor transport.

A third possible mechanism for vapor transport exists at the megadune site. Porous media with very high permeability are susceptible to buoyancy-driven natural convection, which may enhance vapor transport at this site. While there is evidence of natural convection in thin, high-arctic snow covers with large amounts of depth hoar and strong temperature gradients between the air and the underlying soil (Sturm and Johnson, 1991), the layering and permeability profiles of many polar ice sheets often preclude this process. Powers and others (1985) give the critical Rayleigh number for the onset of convection in snow as 10-30. The Rayleigh number modified for porous media describes the balance of buoyancy with viscous forces. When a highly permeable firn exists, such as at this site, a thermal inversion such as that in the firn during the summer-winter transition may set up Bernard convection cells. Taking the permeability of the upper firn as $80 \times 10^{-10} \mathrm{~m}^{2}$, the mixing depth as $5 \mathrm{~m}$, the characteristic temperature difference over the $5 \mathrm{~m}$ as $10 \mathrm{~K}$, the kinematic viscosity of air as $1.37 \times 10^{-5} \mathrm{~m}^{2} \mathrm{~s}^{-1}$, the coefficient of thermal expansion as $0.0035 \mathrm{~K}^{-1}$, and the thermal diffusivity as $0.221 \mathrm{~m}^{2} \mathrm{~s}^{-1}$, then the Rayleigh number is approximately 10 . While this number is near the lower limit for the onset of convection, natural convection clearly cannot be ruled out as an additional mixing mechanism for vapor transport in the near-surface firn; we will be investigating this possibility in ongoing studies.

There are multiple factors that may induce the unusual firn microstructure and properties at this glazed site. The near-surface firn is exposed for long periods of time to temperature gradients that drive vapor transport through diffusion. In addition, processes of wind-driven ventilation and buoyancy-driven natural convection are likely to induce interstitial air movement that also drives vapor transport and firn metamorphism. In the coming year, we will combine additional field measurements at the site with numerical modeling (Albert, 1996, 2002) in order to investigate the relative importance of vapor diffusion, ventilation and natural convection for transport processes and firnification at the megadune site, and the impact of those processes on post-depositional change.

\section{CONCLUSIONS}

Field measurements of the physical properties at a glazed site $\left(80.78^{\circ} \mathrm{S}, 124.5^{\circ} \mathrm{E}\right)$ within a well-defined megadune area in
East Antarctica show that the extensive recrystallization has had a very large impact on the interstitial transport properties. Permeability measurements range from $50 \times 10^{-10}$ to $200 \times 10^{-10} \mathrm{~m}^{2}$, several times higher than similar profiles from Siple Dome, Antarctica, and Summit, Greenland. In the top meter at the site, the firn density ranges from 0.24 to $0.50 \mathrm{~g} \mathrm{~cm}^{-3}$, a range not uncommon in polar firn. Grain-sizes change by layer type and are generally large, and the crystals are faceted. The most coarse-grained layers contain large cup hoar crystals. A clear layering pattern exists, although at this low-accumulation site the predominant layers, especially those deeper than approximately $50 \mathrm{~cm}$, may be indicators of multiple years of a given accumulation pattern. Thin, sometimes discontinuous ice crusts exist primarily near the snow surface, with remnants of ice crusts still visible at depths between $50 \mathrm{~cm}$ and $1 \mathrm{~m}$. Unlike many other polar sites, the firn at this site is sufficiently permeable that buoyancy-driven natural convection may be an important interstitial transport process. Feedback mechanisms between high permeability, long periods of exposure to relatively steep firn temperature gradients near the surface, and possible interstitial ventilation and natural convection over long periods of time have had a profound impact on the microstructure.

In the coming year, additional field measurements will be made at this site and at a nearby rough site in the megadune field. Understanding metamorphism and interstitial transport at cold, low-accumulation sites will help us understand airsnow exchange and the depth of the convective zone for icecore interpretation.

\section{ACKNOWLEDGEMENTS}

We thank the anonymous reviewers and the editor, M. Frezzotti; their constructive comments improved this paper. The 109th Air National Guard and Ken Borek Air provided superior air service in Antarctica. We thank Raytheon Polar Services for logistics and science support in Antarctica, and Ice Coring and Drilling Services for use of the hand-coring device. We also thank L. 'Mac' Cathles for assistance with the figures. The support of the US National Science Foundation through grant NSF-OPP 0125276 is gratefully acknowledged.

\section{REFERENCES}

Albert, M. R. 1996. Modeling heat, mass, and species transport in polar firn. Ann. Glaciol., 23, 138-143.

Albert, M. R. 2002. Effects of snow and firn ventilation on sublimation rates. Ann. Glaciol., 35, 52-56.

Albert, M. R. and F. Perron. 2000. Ice layer and surface crust permeability in a seasonal snowpack. Hydrol. Processes, 14(18), 3207-3214.

Albert, M. R. and E. Shultz. 2002. Snow and firn properties and airsnow transport processes at Summit, Greenland. Atmos. Environ., 36(15-16), 2789-2797.

Albert, M. R., E. F. Shultz and F. E. Perron, Jr. 2000. Snow and firn permeability at Siple Dome, Antarctica. Ann. Glaciol., 31, 353-356.

Brandt, R. E. and S. G. Warren. 1997. Temperature measurements and heat transfer in near-surface snow at the South Pole. J. Glaciol., 43(144), 339-351.

Cunningham, J. and E.D. Waddington. 1993. Air flow and dry deposition of non-sea salt sulfate in polar firn: paleoclimatic implications. Atmos. Environ., 27A(17-18), 2943-2956. 
Ekaykin, A.A., V.Ya. Lipenkov, N.I. Barkov, J.R. Petit and V. Masson-Delmotte. 2002. Spatial and temporal variability in isotope composition of recent snow in the vicinity of Vostok station, Antarctica: implications for ice-core record interpretation. Ann. Glaciol., 35, 181-186.

Fahnestock, M.A., T.A. Scambos, C.A. Shuman, R. J. Arthern, D. P. Winebrenner and R. Kwok. 2000. Snow megadune fields on the East Antarctic Plateau: extreme atmosphere-ice interaction. Geophys. Res. Lett., 27(22), 3719-3722.

Frezzotti, M., S. Gandolfi and S. Urbini. 2002. Snow megadunes in Antarctica: sedimentary structure and genesis. J. Geophys. Res., 107(D18). (10.1029/2001JD000673.)

Fuji, Y. and K. Kusunoki. 1982. The role of sublimation and condensation in the formation of ice sheet surface at Mizuho Station, Antarctica. J. Geophys. Res., 107(D18), 4344.

Fujiwara, K. and Y. Endo. 1971. Preliminary report of glaciological studies. In Murayama, M., ed. Report of the Japanese traverse, Syowa-South Pole 1968-69. Tokyo, National Science Museum. Polar Research Centre, 71-104.

Giovinetto, M. B. 1963. Glaciological studies on the McMurdoSouth Pole traverse, 1960-1961. Ohio State Univ. Inst. Polar Stud. Rep. 7.
Goodwin, I. D. 1990. Snow accumulation and surface topography in the katabatic zone of eastern Wilkes Land, Antarctica. Antarct. Sci., 2(3), 235-242.

Goodwin, I. D., M. Higham, I. Allison and Ren Jiawen. 1994. Accumulation variation in eastern Kemp Land, Antarctica. Ann. Glaciol., 20, 202-206.

Perla, R. 1982. Preparation of section planes in snow specimens. J. Glaciol., 28(98), 199-204.

Picciotto, E.E., W. de Breuck and G. Crozaz. 1970. Snow accumulation along the South Pole-Dronning Maud Land traverse. International Association of Scientific Hydrology Publication 86 (Symposium at Hanover 1968 - Antarctic Glaciological Exploration (ISAGE)), 18-22.

Powers, D., K. O'Neill and S. C. Colbeck. 1985. Theory of natural convection in snow. J. Geophys. Res., 90(D6), 10,641-10,649.

Sturm, M. and J. B. Johnson. 1991. Natural convection in the subarctic snow cover. J. Geophys. Res., 96(B7), 11,65711,671 .

Swithinbank, C. 1988. Antarctica, with sections on the 'Dry Valleys' of Victoria Land by T. J. Chinn, and Landsat images of Antarctica by R. S. Williams, Jr and J. Ferrigno. US Geol. Surv. Prof. Pap. 1386-B. 